\title{
ANALYZE THE INDEPENDENCE OF CLASS VI STUDENT LEARNING ON SCIENCE SUBJECT IN SD NEGERI 5 KEBUMEN
}

\author{
Sittah Amrina Rosyada, Erlina Hanita Irawati, Kartika Christy Suryandari \\ Universitas Sebelas Maret \\ sittahamrina11@gmail.com
}

\begin{tabular}{l} 
Article History \\
\hline accepted 30/09/2018 \\
approved 12/10/2018 \\
published 30/10/2018 \\
\hline
\end{tabular}

Keywords

Independence Learning, Science

\begin{abstract}
Learning independence is needed for students so that the learning process does not depend on others. This is based on indicators of learning independence which include responsibility, able to solve problems, use learning resources, and confidence. Seeing the importance of learning independence for students, independence must exist in all subjects including science. More indicators are achieved showing students have high science learning independence. The purpose of this study was to describe the learning independence of class VI student learning in science subjects in SD Negeri 5 Kebumen academic Years 2018/2019. This research is a qualitative descriptive study that uses data collection techniques in the form of observation, questionnaires, and interviews. Analysis of the data used quantitatively and qualitatively. After analyzing the data, the average percentage of indicators was $31 \%$. The results of the analysis, it can be concluded that the independence of class VI student learning in science subjects in SD Negeri 5 Kebumen was categorized as not good.
\end{abstract}

Social, Humanities, and Education Studies (SHEs): Conference Series https://jurnal.uns.ac.id/shes
p-ISSN 2620-9284

e-ISSN 2620-9292 


\section{PENDAHULUAN}

Perkembangan zaman yang semakin cepat menuntut setiap manusia untuk membekali diri dengan ilmu pengetahuan dan keahlian (skill). Melihat tuntutan ini, maka mau tidak mau setiap orang harus berupaya sekuat tenaga untuk memperoleh ilmu pengetahuan dan juga keahlian jika ingin sukses dalam kehidupannya. Satu-satunya jalan yang bisa ditempuh adalah dengan pendidikan. Menurut Syah (2012: 1) pendidikan pada dasarnya adalah usaha sadar untuk menumbuhkembangkan potensi sumber daya manusia siswa dengan cara mendorong dan memfasilitasi kegiatan belajar mereka.

Sekolah sebagai sarana pendidikan bagi masyarakat merupakan tempat belajar bagi para siswa untuk mencapai suatu tujuan. Menurut Sanjaya (2008: 251) tujuan lembaga pendidikan khususnya sekolah adalah mempersiapkan siswa agar dapat hidup di masyarakat. Tugas pendidikan yang berlangsung di sekolah adalah mengembangkan manusia menjadi subjek yang aktif yang mampu mengembangkan seluruh potensi yang dimilikinya agar mereka hidup dam dapat mengembangkan kehidupannya di masyarakat yang selalu berubah. Untuk mencapai itu semua diperlukan upaya-upaya sadar dan nyata dari siswa itu sendiri. Upaya yang bisa dilakukan siswa adalah dengan melakukan belajar secara teratur, mandiri, dan disiplin baik di sekolah maupun di rumah.

Kemandirian adalah usaha untuk mengendalikan dan mengatur pikiran, perasaan, dan tindakan sendiri secara bebas serta berusaha sendiri untuk mengatasi perasaan-perasaan malu dan keragu-raguan (Desmita, 2014: 185). Pentingnya kemandirian bagi peserta didik dapat dilihat dari fenomena-fenomena yang sangat membutuhkan perhatian dunia pendidikan. Fenomena yang terjadi dalam konteks belajar adalah peserta didik yang kurang mandiri dalam belajar. Kemandirian siswa dalam belajar merupakan suatu hal yang sangat penting dan perlu dikembangkan pada siswa.

Kemandirian belajar diperlukan bagi peserta didik agar dalam proses belajarnya tidak bergantung kepada orang lain. Kemandirian dalam belajar diartikan sebagai aktivitas belajar yang didorong oleh kemauan sendiri. Tahar \& Enceng (2006: 92) mengemukakan bahwa kemandirian belajar adalah proses ketika individu mengambil inisiatif sendiri, dengan atau tanpa bantuan orang lain, untuk mendiagnosis kebutuhan belajar, memformulasikan tujuan belajar, mengidentifikasi sumber belajar, memilih dan menentukkan pendekatan strategi belajar, dan melakukan evaluasi hasil belajar yang dicapai. Belajar dapat dilakukan dimana saja, kapan saja, dan dengan siapa saja. Sugihartono, dkk (2007: 74) mendefinisikan belajar sebagai perubahan yang relatif permanen karena adanya pengalaman. Pengalaman tersebut diperoleh dari interaksi dengan lingkungan sekitar, baik dari proses mengamati, meniru, maupun memodifikasi melalui mata pelajaran yang diajarkan di sekolah, salah satunya IImu Pengetahuan Alam (IPA).

IPA merupakan salah satu mata pelajaran wajib pada kurikulum pendidikan dasar dan menengah. Samatowa (2006: 3) mengungkapkan empat alasan perlunya IPA diajarkan di SD, yaitu 1) karena IPA merupakan dasar teknologi sehingga berfaedah bagi suatu bangsa, 2) IPA memberikan kesempatan berpikir kritis jika IPA diajarkan salah satunya dengan mengikuti metode menentukan sendiri, 3) IPA tidaklah merupakan mata pelajaran yang bersifat hafalan belaka bila IPA diajarkan melalui percobaan-percobaan yang dilakukan sendiri oleh anak, dan 4) IPA mempunyai nilainilai pendidikan yang dapat membentuk kepribadian anak secara keseluruhan. Dengan demikian, IPA sangat berperan penting dalam membentuk kemandirian belajar siswa. 
Berdasarkan uraian tentang kemandirian belajar dan pembelajaran IPA tersebut, siswa SD diharapkan memiliki kemandirian belajar dalam pembelajaran IPA. Kemandirian belajar yang dimaksud adalah proses kegiatan belajar siswa yang dapat mengambil inisiatif sendiri, tanpa tergantung dengan orang lain, untuk merencanakan, melakukan, dan mengevaluasi kegiatan belajarnya pada pembelajaran IPA.

Kemandirian belajar ditandai dengan indikator tanggung jawab, mampu memecahkan masalah, menggunakan sumber belajar, percaya diri, dan dapat mengambil keputusan. Semakin banyak indikator yang dicapai menunjukkan siswa memiliki kemandirian belajar IPA yang tinggi.

Berdasarkan observasi awal di kelas VI SD Negeri 5 Kebumen menunjukkan bahwa terdapat siswa yang belum memiliki kemandirian belajar yang baik. Hal tersebut tampak dari gejala-gejala yaitu: siswa lebih memilih bermain ketika guru tidak di kelas, asik mengobrol dengan teman saat guru menjelaskan, sering mencontek saat ulangan.

Atas dasar paparan latar belakang tersebut, penelitian ini bertujuan untuk mendeskripsikan kemandirian belajar siswa kelas VI pada mata pelajaran IPA di SD Negeri 5 Kebumen Tahun Ajaran 2018/2019.

\section{METODE}

Pendekatan yang digunakan dalam penelitian ini adalah kualitatif. Jenis penelitian ini adalah penelitian deskriptif dimana peneliti dimaksudkan untuk menyelidiki keadaan, kondisi, situasi, peristiwa, kegiatan, yang hasilnya dipaparkan dalam bentuk laporan penelitian (Arikunto, 2010:3). Sedangkan jenis penelitian yang digunakan adalah deskriptif yaitu dengan mengungkapkan data sekarang berdasarkan fakta-fakta yang tampak atau sebagaimana adanya pada saat penelitian dilakukan. Dalam penelitian ini yang menjadi subjek penelitian adalah siswa kelas VI di SD Negeri 5 Kebumen yang berjumlah 39 peserta didik.

Dalam memperoleh data pada penelitian ini, peneliti menggunakan teknik observasi, angket, dan wawancara. Observasi dan angket dilakukan dengan tujuan untuk melihat aktivitas belajar siswa, kemandirian belajar siswa selama proses pembelajaran berlangsung. Angket yang digunakan dalam penelitian ini adalah angket terstruktur yang disajikan dalam bentuk pernyataan, responden diminta untuk memilih satu jawaban yang paling sesuai dengan karakteristik dirinya dengan memberikan tanda check list $(\sqrt{ })$ pada salah satu alternatif jawaban. Kemudian dilakukan wawancara untuk memperkuat hasil dari observasi dan angket tersebut. Wawancara yang digunakan dalam penelitian ini dengan mengajukan pertanyaan-pertanyaan terstruktur karena peneliti menggunakan pedoman wawancara yang disusun secara sistematis dan lengkap untuk mengumpulkan data yag dicari. Analisis data yang digunakan secara kuantitatif dan kualitatif.

\section{HASIL DAN PEMBAHASAN}

Untuk memperoleh data tentang kemandirian belajar siswa kelas VI pada mata pelajaran IPA di SD Negeri 5 Kebumen, maka peneliti menyebarkan angket sebanyak 20 item pernyataan. Masing-masing pernyataan memiliki 2 alternatif jawaban $\mathrm{Ya} /$ Tidak. Untuk menentukan nilai kuantitatif kemandirian belajar siswa kelas VI tersebut adalah dengan menjumlahkan skor jawaban angket. 
Tabel 1. Kategori Kemandirian Belajar Siswa Kelas VI

\begin{tabular}{lc}
\hline \multicolumn{1}{c}{ Indikator } & $\begin{array}{c}\text { Rata-rata } \\
\text { persentase } \\
\text { indikator }\end{array}$ \\
\hline Tanggung jawab & $48,72 \%$ \\
Dapat memecahkan masalah & $79,49 \%$ \\
Menggunakan sumber belajar & $51,28 \%$ \\
Percaya diri & $66,66 \%$ \\
Dapat mengambil keputusan & $17,95 \%$ \\
Total jumlah rata-rata presentase akhir & $52,82 \%$ \\
\hline
\end{tabular}

Berdasarkan tabel 1 di atas menunjukkan bahwa hasil tersebut terlihat jelas dari rincian data setiap indikator sebagai berikut : tanggung jawab memperoleh presentase sebesar $48,72 \%$. Dapat memecahkan masalah memperoleh presentase sebesar 79,49\%. Menggunakan sumber belajar memperoleh presentase sebesar $51,28 \%$. Percaya diri memperoleh presentase sebesar 66,66\%. Dapat mengambil keputusan memperoleh presentase 17,95\%.

Setelah skoring data dilakukan maka selanjutnya peneliti menjelaskan hasil dari pengolahan skoring data tersebut untuk mencari presentase dari tiap-tiap instrumen angket analisis kemandirian belajar siswa kelas VI pada mata pelajaran IPA.

Tanggung jawab dapat diketahui bahwa siswa secara keseluruhan baru belajar ketika diperintah oleh guru. Jawaban siswa kelas VI tentang kemandirian belajar dengan indikator tanggung jawab mendapatkan rata-rata presentase sebesar $48,72 \%$ dengan kategori kurang baik. Jawaban siswa tentang tetap belajar ketika tidak ada guru di kelas diperoleh presentase sebesar $46 \%$. Jawaban siswa tentang memilih bermain ketika tidak ada guru di kelas diperoleh presentase sebesar $32 \%$. Jawaban siswa tentang tetap belajar walaupun tidak ada ulangan diperoleh presentase sebesar $51 \%$. Jawaban siswa tentang belajar ketika ada ulangan diperoleh presentase sebesar $60 \%$. Jawaban siswa tentang belajar sendiri tanpa diperintah guru diperoleh presentase sebesar 54\%. Jawaban siswa tentang baru belajar ketika diperintah guru diperoleh presentase sebesar 32\%.

Dapat memecahkan masalah dapat diketahui bahwa indikator tentang kemandirian belajar dengan rata-rata indikator sebesar $79,49 \%$ dengan kategori cukup baik. Jawaban siswa tentang mengerjakan sendiri tugas IPA yang diberikan guru diperoleh presentase sebesar $79 \%$. Jawaban siswa tentang mencontek jawaban IPA milik teman diperoleh presentase sebesar $43 \%$. Jawaban siswa tentang mengerjakan sendiri latihan soal IPA diperoleh presentase sebesar $77 \%$. Jawaban siswa tentang bertanya kepada teman ketika kesulitan mengerjakan latihan soal IPA diperoleh presentase sebesar $60 \%$. Jawaban siswa tentang mencontek jawaban latihan soal IPA milik teman diperoleh presentase sebesar $47 \%$.

Menggunakan sumber belajar dapat diketahui bahwa indikator tentang kemandirian belajar dengan rata-rata indikator sebesar $51,28 \%$ dengan kategori kurang baik. Jawaban siswa tentang menyiapkan buku IPA pada malam hari sebelum pembelajaran diperoleh presentase sebesar $77 \%$. Jawaban siswa tentang membaca buku IPA saat kesulitan mengerjakan soal IPA diperoleh presentase sebesar $91 \%$. Jawaban siswa tentang membaca buku IPA hanya jika ada ulangan diperoleh presentase sebesar $49 \%$.

Percaya diri dapat diketahui bahwa indikator tentang kemandirian belajar dengan rata-rata indikator sebesar $66,66 \%$ dengan kategori cukup baik. Jawaban siswa tentang mengerjakan sendiri soal ulangan harian IPA diperoleh presentase 
sebesar $72 \%$. Jawaban siswa tentang mencontek jawaban teman ketika mengerjakan soal ulangan harian IPA diperoleh presentase sebesar 48\%. Jawaban siswa tentang senang berpendapat saat berkelompok mengerjakan tugas IPA diperoleh presentase sebesar 79\%. Jawaban siswa tentang lebih memilih diam saat berkelompok mengerjakan tugas IPA diperoleh presentase sebesar 55\%.

Dapat mengambil keputusan dapat diketahui bahwa indikator tentang kemandirian belajar dengan rata-rata indikator sebesar 17,95\% dengan kategori kurang baik. Jawaban siswa tentang dapat menjawab soal IPA dengan cepat dan tepat diperoleh presentase sebesar $26 \%$. Jawaban siswa tentang belum berpikir untuk menjawab soal IPA diperoleh presentase sebesar $62 \%$.

Dengan demikian, hasil penelitian yang ada sesuai dengan pendapat Tahar \& Enceng (2006: 92) yang mengemukakan bahwa "Kemandirian belajar adalah proses ketika individu mengambil inisiatif sendiri, dengan atau tanpa bantuan orang lain, untuk mendiagnosis kebutuhan belajar, memformulasikan tujuan belajar, mengidentifikasi sumber belajar, memilih dan menentukkan pendekatan strategi belajar, dan melakukan evaluasi hasil belajar yang dicapai".

Untuk memperkuat hasil angket, peneliti melakukan wawancara terhadap 6 orang siswa yang dipilih secara acak. Peneliti membuat pedoman wawancara yang terdiri dari 11 item pertanyaan. Wawancara tersebut bersifat terbuka dengan narasumber memberikan penjelasan lengkap, tidak merupakan jawaban pilihan.

Hasil wawancara menunjukkan bahwa siswa kelas VI belum memiliki tanggung jawab dalam belajarnya. Mereka lebih memilih bermain ketika tidak ada guru di kelas. Sebagian besar siswa kelas VI belajar jika hanya ada ulangan dan disuruh oleh guru. Siswa kelas VI cukup baik dalam memecahkan masalah. Mereka berusaha mengerjakan sendiri tugas IPA yang diberikan oleh guru dan mau bertanya ketika menemukan kesulitan dalam mengerjakan soal. Siswa kelas VI masih kurang dalam menggunakan sumber belajar. Mereka tidak terbiasa membaca buku IPA, karena lebih menyukai mata pelajaran lain. Untuk tingkat percaya diri sudah baik. Mereka mampu berpendapat saat diskusi kelompok mengerjakan tugas IPA. Namun, dalam mengambil keputusan mereka masih sangat kurang, terbukti mereka belum bisa menjawab soal IPA dengan cepat dan tepat.

\section{SIMPULAN}

Berdasarkan hasil penelitian, maka ditarik kesimpulan secara umum bahwa kemandirian belajar siswa kelas VI pada mata pelajaran IPA di SD Negeri 5 Kebumen termasuk dalam kategori "kurang baik".

Secara khusus dapat disimpulkan sebagai berikut: (1) Tanggung jawab dalam belajar masuk kategori "kurang baik". (2) Dapat memecahkan masalah diartikan masuk kategori "cukup baik". (3) Menggunakan sumber belajar diartikan masuk kategori "kurang baik". (4) Percaya diri dalam proses belajar diartikan masuk kategori "cukup baik". (5) Dapat mengambil keputusan diartikam masuk kategori "kurang baik".

Indikator yang paling menonjol yaitu dapat memecahkan masalah dengan presentase rata-rata sebesar $79,49 \%$. Sebagian besar siswa kelas VI SD Negeri 5 Kebumen mengerjakan sendiri tugas IPA yang diberikan guru. Sedangkan indikator yang paling kurang yaitu dalam mengambil keputusan dengan presentase rata-rata sebesar $17,95 \%$. Mereka belum bisa mengambil keputusan dengan cepat dan tepat.

Sehingga pada penelitian selanjutnya perlu dilakukan kajian yang lebih mendalam untuk meningkatkan kemandirian belajar pada mata pelajaran IPA di SD Negeri 5 Kebumen. 


\section{DAFTAR PUSTAKA}

Arikunto, S. (2010). Prosedur Penelitian Suatu Pendekatan Praktik. Jakarta: Rineka Cipta.

Desmita. (2014). Psikologi Perkembangan Peserta Didik Panduan bagi Orang Tua dan Guru dalam Memahami Psikologi Anak. Bandung : Remaja Rosdakarya

Tahar, I \& Enceng. (2006). Hubungan Kemandirian Belajar dan Hasil Belajar pada Pendidikan Jarak Jauh. Jurnal Pendidikan Terbuka dan Jarak Jauh (Volume 7, Nomor 2, September 2006). 91-101.

Samatowa, U. (2010). Pembelajaran IPA di Sekolah Dasar. Jakarta : Indeks.

Sanjaya, W.(2008). Kurikulum dan Pembelajaran. Jakarta : Kencana

Sugihartono, dkk. (2007). Psikologi Pendidikan. Yogyakarta:UNY Press.

Syah, M. (2012). Psikologi Belajar. Jakarta: Rajawali Press. 